\title{
THRILLS AND PERILS OF COUNTRY BANKING
}

\author{
By E. A. JoHNSON*
}

Perhaps, had I not made the mid-winter trip to my old home town of Bussey, I might have kept my wellintended resolution and written finis to further literary efforts. However, since returning from my semi-annual visit to my old home, and recalling many happy days spent in the lobby of our old bank, where among the throngs passing in and out I would occasionally see the familiar face of one or more with whom I had transacted business thirty, thirty-five or forty, even one or two dating back to within a few months of fifty years ago, I am inspired anew.

The meeting and greeting of friends, who have grown old with me, the grasp of their hands and sound of their voices gave me inexpressible pleasure. With some old Father Time has dealt less gently than with myself, as many now are stooped by the weight of years, dim of eye, worn by toil and wasted by the infirmities of age.

Almost invariably each would recount some transaction or incident still fresh in their minds, which had completely passed from my memory, yet their mention in detail would restore my own recollection. Some were quite complimentary, insisting that the favor or help extended at a time needed had materially contributed to their success. To all such I would suggest that inasmuch as they paid for the accommodation, they were neither then nor now under any obligation to me, yet I confess their expressions of gratitude gave me such a sense of pleasure that I almost could wish I might live my life over again and give still more of sympathy and service to my fellow man. But, such as it was, it was a heritage from my good old Christian mother, who throughout all her life had sympathy for and gave help to the less fortunate.

*Life Memoirs of E. A. Johnson, pp. 113-127 written in 1942 upon request of his children for preservation among the family records. This and other chapters typifying more recent decades of Iowa life, published by permission from copy filed in Iowa Department of History and Archives. 
It is one of the sustaining pleasures of my life to recall the name of a certain young man then just entering the battle of life to whom I was able to extend counsel, encouragement and financial assistance. Just one instance shall I here relate. $\mathrm{He}$ is now, and for many years has been one of the substantial citizens of the community. I had not seen him for several years. We shook hands and were having a good old-fashioned visit, when he suddenly asked if I remembered his first call at the bank. I did not, nor can I yet remember the circumstances, as he briefly related the interesting story.

He was an orphan boy, recently married and living on a rented farm a half dozen miles from town. At the end of the crop season he had on hand a lot of feed, "roughage" we then and yet call it, which had little dollar value as such. But he had found a bunch of calves that he could buy for $\$ 350.00$, whereby he could use this feed to good advantage, $B U T$ he had no money. A stranger he was in the community, first year "on his own" and he knew of no one who would endorse his note at the bank, but how he wanted those calves. For days he pondered and meditated on how he could possess the calves. Finally, though not with much hope of success, he mustered up enough courage to call alone at the bank. In relating the story he said he cannot even yet understand why I loaned him that money, when the property statement he made showed the value of every thing he possessed was less than the amount of the loan he sought. But out of the bank he went with the money in his pocket, bought the calves, and to repeat his own words, "Elmer Johnson, the money you loaned me that day was my start."

The transaction was thirty-seven years ago, and from that day on he has been a good friend, a valued customer, and today this same bank would be glad to loan him on individual note far more than he would ever ask for. My talk with him was like turning back the hands of the clock, and I recalled other similar cases. However, I should here confess I was not always so fortunate 
in my judgment, and occasional losses resulted when sympathy replaced judgment; yet, in the main, the final record would show a favorable balance sheet.

\section{EARLY LIFE ON FARM}

My wife and I occupied our little rural home in March 1889. Our farm, adjoining that on which I grew to manhood, was a modest one on which there was a comparatively new four-room house, not lavishly though comfortably furnished. The little eighty-acre farm was of average fertility and topography, as compared to other farms in the neighborhood, needing only intelligent management, proper and sufficient tillage to yield compensatory crops adapted to the locality. We had two good teams of horses, one of which my wife owned at the time of our marriage.

I possessed a couple of good cows and two others were added by purchase. In the line of farm equipment, I had a farm wagon, a corn planter, corn cultivator and a few others. On my father's farm was a complete line of farm machinery and as he was renting the crop land all his farm tools were mine to use as though I owned them. The season of 1889 produced big crop yields of all kinds. Though low prices prevailed, the heavy yields gave fair returns. The season of 1890 was one of poor yields and high prices. The seasons of 1891-92 gave us fair yields and satisfactory gains and we were satisfied and happy.

Until late in June, 1892, no thought had ever occurred to us, of any way of life, employment of our time and minds, other than that of the happy and contented life on our little farm. Along in the mid-eighties the Schee brothers, James, Nathan and John F., engaged in the banking business in Milo, Warren county, Iowa. Under the highly efficient management of John F., the youngest of the three, the business developed into a very profitable venture. The two older brothers, James and Nathan, decided to expand and engage in the same line in 
other favorable localities in need of banking facilities. Among others they decided to investigate the town of Bussey as a possible location for a bank.

In pursuance of this idea Nathan came to my parents' home for the dual purpose of a visit with his sister and family and to investigate the proposed bank project. During his visit in our home we discussed the bank proposition quite fully. I was invited to assist in the organization and if successful I would be the cashier. After serious consideration I decided to accept and during the two following days Nathan and I called on some of the more progressive men of the town and several leading farmers in the vicinity, with the result that before the week end the embryo bank was in process of organization with the following list of stockholders: Jesse Bussey, James A. Bussey, Clinton Fergus, Jas. Sims, Asa Johnson, W. E. Faegins, Nathan Schee, James Schee, and E. A. Johnson.

\section{TRAINING AS A BANKER}

It was agreed the bank would open by August 1, or as soon thereafter as arrangements could be made. As I never had any banking experience it was planned that I spend the month of July in their Milo bank under the tutorship of their highly efficient cashier, John F. Schee. Before leaving for my training period I arranged with Milburn Knapp, then living in Hamilton, to move on the farm, finish cultivation and harvesting of the growing crops and rent the farm for the following year.

Incidentally, my last day's work on a farm for a period of thirty-one years was on July 3, 1892, and with a two-horse, one-row walking-cultivator I cultivated ten acres of growing corn. When I tell you that to cultivate six or seven acres with that sort of equipment was considered a full day's work, you may know it was something beyond the ordinary. 
The following day, July 4, I kissed my wife and babies goodbye, rode to Bussey with my parents, boarded the train to Pleasantville, arriving there about 1:00 p.m., and after a light lunch departed on foot toward Milo, the home of my uncle, James Schee, sixteen miles distant. All teams on the road-that was before automobiles had even been dreamed of-were going in the opposite direction to that I was traveling, and not a single team overtook me; yet, burdened with a heavy suit case, I reached my uncle's home about six o'clock in the evening. There I remained the night, and the following morning with my uncle I rode to Milo and entered the bank where I was supposed within a month to become an expert banker. Laying aside my coat, I was set to work immediately by the busy cashier and through his instruction, observation and practice I acquired and learned a little of the technique of banking and finance. During the month at Kansas City Nathan bought a big three-ton fire- and burglar-proof safe, and my preceptor ordered for the about-to-be-born bank a full line of stationery and books that would be required by the new venture.

About the middle of the month on horseback I made the forty-five mile trip for an over-Sunday visit with my family yet on the farm. Enroute I stopped at Knoxville and at the Citizens National Bank, that had been selected as one of our correspondents, made a deposit to the credit of the yet unborn, though already named, Bank of Bussey. There I met the genial and affable cashier, Lafe S. Collins, the beginning of a friendly, business and social relationship that continued uninterrupted to the end of his life thirty-five years later.

After the all too-short visit to my home and family I returned to my apprenticeship at the Bank of Milo and there remained until notified by wire July 30 that our safe had arrived. The next day Nathan and I drove to Bussey and on August 1, with the help of more volunteers than we could use, the ponderous safe was removed from the car and placed in the ten by twenty-foot front room of a vacant building, on the west side of Merrill 
street, midway between Fourth and Fifth avenues. An eight-foot section of an old discarded grocery counter, over the top of which was spread a piece of white oil cloth, served as office desk and counter. No sort of rail, screen or other protective device was available, and the only way to prevent customers or loafers from using it as a seat, or to recline upon, was to keep the top covered with books, papers or other paraphernalia of the new-born institution. Behind the counter was a chair for the cashier, the big safe and a small box to support the coin tray and currency rack. Thus, late in the evening on August 1, 1892, the institution was made ready for the grand opening on the following morning.

\section{BANK OF BUSSEY OPENS}

Later in the evening I went to my farm home for the night, but returned early the next morning to prepare for the great event. The big safe was opened and all the money it contained, some $\$ 200.00$ in bills and little silver placed within plain view from the lobby. Bedecked in a clean shirt and freshly scoured celluloid collar, promptly at the stroke of eight bells the great door grated on its rusty hinges and swung wide open, and I in my most beguiling smile stepped into the opening to greet the vast throngs that-were not there. I looked up the street, down the avenue, but the one sign of life to greet my vision was a fisticuff between two pre-teenage lads, in dispute over a canine fight, the curs belonging to the two belligerents. Evidently the townspeople and country-side had forgotten, or could not believe that a great financial institution awaited their distressed calls for financial relief at legal rates on all amply secured obligations. Of one thing I was sure. We were enjoying a situation, the like of which years later would have brought joy to many a harrassed banker's heart; there was no run on $O U R$ bank. Then I recalled that once upon a time some poet, or maybe a philosopher, wrote that "All things come to him who patiently waits," and I waited, but not for long. 
Near mid-forenoon came Jesse Bussey, he for whom the town was named, and opened an account for J. Bussey \& Son. A little later came a Mrs. A. B. Lyman who became recipient of Certificate of Deposit No. 1, in exchange for $\$ 215.00$ in mouldy bills which she declared she and her spouse had with much fear and trembling long kept hidden in their domicile. Shortly after lunch came one John Mehana, an old soldier, while not blind, yet was drawing a blind man's pension of $\$ 72.00$ per month, 'tho at the moment penniless, and gave his thirty-day note for a $\$ 15.00$ loan, for which I charged him twentyfive cents interest. To his observation this was "a rather stiff rate," he was only partially mollified when I explained we would make no loan of any amount for any length of time for less than two bits, that a thirtyday $\$ 25.00$ loan would cost no more he departed muttering that next time he would borrow the larger sum. Thus, at the close of our first day, I was able to enter on our books: Bills Receivable $\$ 15.00$, Interest \& Discounts .25 , and slightly more than $\$ 1000.00$ deposits.

In this $\mathrm{AD} 1942$, I read in the public press that "business as usual" is regarded as a sort of crime, or at least evidence of a lack of patriotism, yet it began in 1892, as by the end of the week, the Bank of Bussey was an established institution. With growing pains it has so continued to this day, within a few months of fifty years, with but a single interruption, being closed three days in 1933 by presidential proclamation. Before the end of our first week all our subscribed capital of $\$ 15,000.00$ had been paid in, a board of directors chosen, from among whom Jesse Bussey had been elected president at no salary, and E. A. Johnson formally elected cashier for one year at the munificent salary of $\$ 313.00$ or $\$ 1.00$ per day. I, for once in my life was lucky, as it being leap year, otherwise my salary would have been $\$ 1.00$ less. I recall how I swelled with pride when at the end of six months I could report $\$ 10,000.00$ deposits, and at the year end $\$ 30,000.00$ deposits, net earnings $\$ 1,096.00$ and volume of business just under one million. 


\section{T'WENTY-FIVE YEAR RECORD}

Without undertaking to detail our growth year by year, the records disclose that when I retired as cashier March 1, 1918, we had in excess of a quarter million deposits, had paid stockholders cash dividends of $512 \%$, a trifle more than $20 \%$ per annum, and book value of stock $\$ 180.00$ per $\$ 100.00$ share. Furthermore, to the best of my recollection, not to exceed a dozen suits had been filed, most of them in justice of the peace courts, and I believe not to exceed a half-dozen foreclosures on mortgages both real and chattel. This is a record of which I am proud, although the patrons of the bank are entitled to more credit than the management. In that quarter century lived a class of people who, except in a few notable cases, were honest, honorable and upright, recognizing the solemnity of contract, and when they contracted a debt did so with the expectation of repaying the money borrowed. It was with such that I had my business experience, when character was regarded as an asset.

Only one other claim will I here make. I cannot recall a single instance of any man or woman ever being required or asked to pay usurious interest, or any advantage taken of an unfortunate situation facing or in which they found themselves. Never any harsh or oppressive measures resorted to so long as an honest effort was being made to liquidate his or her obligation. Again reaffirming my faith in the masses I did have a few painful individual experiences with some of the notable exceptions, a few of whom yet live in the vicinity.

Our old bank building was a big, three-story, sheet steel-covered structure constructed in 1894 . On the night of February 29, 1912, we were attending services at the newly rebuilt Methodist church. The meeting was about half over when a messenger quietly slipped into the building and whispered to me that the bank building was on fire. I left the church on the run and when I reached the street a block east I saw a small flame burning in the roof. In less time than it takes to tell it the 
alarm spread and people from all over town came running to the fire. At that time the only means of fighting fire was by bucket brigade, and strange as it may seem, there was no ladder in town long enough to reach the roof, and all knew the building was doomed.

Willing hands helped remove the movable furniture and equipment from the bank, and the merchandise from the store room in the building, while a half-hundred others with water-filled pails lent their assistance to the saving of other nearby buildings, so far as was possible to so do. The sheet metal siding was some measure of assistance in preventing spread of the flames, but despite all efforts about every thing on the quarter block was destroyed. The contents of the bank vault were uninjured, though the heavy steel vault door was so hot it could not be opened for three days.

Early the following morning, Friday, a force of men was set to work erecting a temporary frame building and by working long hours at top speed it was completed late Saturday night. An order for new supplies was immediately placed with a Des Moines bank supply house. On Monday we succeeded in opening the vault door, and moved the safe to the new temporary quarters. Tuesday the new supplies arrived and again we were doing business as usual.

A force of men was put to work moving the debris from the burned-over premises, excavation for a full basement started, material ordered and erection of the fine building that now houses the bank was soon under way. We continued in the temporary building until completion of the new one, into which we moved in early July.

\section{LOYALTy OF a VALUed FRIEND}

Earlier in this narrative mention was made of my acquaintance with Lafe S. Collins, cashier of the Citizens Bank of Knoxville. On numerous occasions covering a period of years he had suggested an association that would bring me into some of the various business activi- 
ties in which he was interested, chief of which, in addition to his bank, was the Collins Oil Company that was doing an enormous and profitable business; but I had no desire to retire from the bank, with which I had been since its beginning and had declined all overtures that would take me away from it. Early in the morning following the holocaust he came to Bussey to see me and again renewed his efforts to enlist my services with him. He owned a controlling interest in a bank in a neighboring county seat town, with the official personnel of which he was not fully satisfied, and urged that I go to that bank either as cashier or president, whichever I preferred. He agreed that his IKnoxville bank would take excellent care of our Bussey customers, but I declined.

Again, in 1917, when I made the business mistake of my life by going to Council Bluffs, he endeavored to dissuade me, urging I go to Knoxville instead, as he said "not to work, but to help manage" his business. He said regardless of what the Council Bluffs people agreed to pay me, he would do better. But I had given my word, and had invested money in the proposition, believing it had a promising future, and again I declined the Collins proposition. Five years later I was broke, dead broke, and after a thirty-one-year vacation from farm life, at the age of fifty-six years, we moved to and on a New York farm and started all over again. We moved to and possessed the New York farm about the middle of August, 1923.

A couple months later I was aroused from my midnight slumbers by the loud ringing of the telephone. I arose, went to the phone and was told I was being called by a party in Iowa. Somewhat alarmed, lest it be a matter of death or severe illness of a near relative, I awaited the call from the Iowa end of the line. Contact was soon made and I was surprised to distinctly hear the voice of Lafe Collins asking if I would consider returning to Iowa to take charge of a bank in (naming the town), the purchase of which he was negotiating, 
the bank's agent being then in his office. Like a woman to whom a proposal of marriage had just been made, it "was so sudden," and I told him I could not give an immediate off-hand reply. He then asked if I would return to Knoxville for a conference, he to pay all expense of the trip regardless of my decision. My wife had arisen from her bed and was standing at my side when Collins proposed the trip back. Nodding her approval I told him I would go. Within a day or so I was enroute and within another day or two was in his office in Knoxville.

\section{DEFLATION AFTER WORLD WAR I}

By this time, and for some weeks previously, serious trouble was beginning to develop in and among Iowa banks, and as I passed through Chicago I learned from a former Des Moines banker then connected with a big Chicago bank, that the bank under consideration was very hard up and advised extreme caution. When I arrived in Knoxville I told Mr. Collins of the tip I had received, and that $I$ did not care to take a chance of further trouble. As a matter of fact his ardor had already cooled toward that bank and it was immediately dropped from consideration.

He had still another in mind, a bank at Atlantic that was for sale and suggested we go together to investigate, but I seemed to have lost all interest in banks and banking and so told him. He then told me he could and would buy an old established produce house in Knoxville if I would return and take the management of it.

Again the disastrous results of taking on at my age the responsibility and management of a business with which I was not familiar loomed before me and this I declined to consider. He was aware of the reverses I had met and his motives were to help me, he having more faith and confidence than I in my ability. While I declined all his offers I fully appreciated his consideration and shall always revere his memory as a true and loyal friend. 


\section{BILL RICHARD'S MissteP}

A quarter century in any line of business endeavor will provide an abundance of thrills, but banking may perhaps afford a greater number and variety than many others. Bankers are frequently accused of giving freely of advice when to their advantage and benefit, though this is rarely if ever true. Bankers universally are interested in the success and safety of their customers and will never purposely mislead nor permit others to do so, if they can prevent it.

I cannot now recall the exact date, though I think about the year 1916-17, Sarah Sullivan, then a resident of Hamilton, sold the small farm inherited from her father, receiving some three thousand dollars in cash, which she deposited in our bank. One, Bill Richards, a deputy U. S. marshal, residing in Des Moines, appeared to have had much business, official or otherwise in and about Hamilton and was boarding at the Sullivan home. On a certain afternoon just at the closing hour, Mrs. Sullivan came in and asked for her entire balance in cash. Surprised that she would wish to withdraw such a large sum in cash at that hour of the day I suggested she leave it until morning, or take a bank draft which ordinarily would be accepted as cash in any legitimate transaction. I warned her of the danger of keeping such a large sum of money in her home over night, but she insisted and cash was paid to her. Early the following morning came the report of an attempted robbery at her home and one of the would-be thieves was shot and badly wounded by that lady's husband.

The story as unfolded revealed that her supposedly good friend Richards had told her confidentially that the Bank of Bussey was on the verge of closing, would in fact not open on the morrow, and that she must go to Bussey, get her money and take it to the Lovilia bank for safe keeping. He also warned her to not accept a bank draft or check, as such issued by a closed bank would be worthless. This important advice was so timed 
that she could not possibly drive to Bussey, get her money, then drive the six miles to Lovilia before that bank was closed for the day and the time lock on guard, and no banker would accept such a sum to hold outside the vault over night with no protection. Suspicion almost immediately pointed to Richards as an accomplice in the affair, and at the court trial later it was proven he had imported a Creston crook to do the dirty work under his direction, and both he and his copartner in crime, who recovered from the gunshot wound, were sent to prison for long terms of years.

\section{EFFECTS OF Limiting CiRculation}

During my banking career the fraternity had never experienced any such difficulties as that following the deflation policy of the Federal Reserve board inaugurated late in 1920, though we did have a few short-time flurries, the most important being the one in 1907, commonly known as the "Banker's Panic." Economic conditions for years had been good, business men and farmers were prosperous and making money, and bankers experiencing no untoward conditions. In the great midwest as we turned the keys in our bank doors late Saturday evening not a cloud appeared in the financial skies. On the following Monday morning an absolute and total eclipse covered the financial firmament, though visible only to the bankers in the great eastern metropolitan cities. We, the Bank of Bussey, as well as the great army of mid-west bankers, knew nothing of it until arrival of the great morning daily papers.

This was no panic of crazy mad depositors in an insane rush to withdraw their savings, but it appeared some big New York bank had gotten into some sort of difficulty and had made the astounding discovery that if all depositors at one and the same moment should demand $A L L$ their balances there was not a sufficiency of cash with which to pay; therefore the only thing to do was to limit the daily cash withdrawals to a nominal 
sum, and the excess amount to be paid in a sort of token money called cashier checks.

As for our bank we were constantly increasing our cash on hand, gaining in actual currency, taking in over the counter far more than we were paying out, and as a result were obliged to ship by prepaid express to our city correspondents the excess over and above our daily requirements. In fact the train that brought the Chicago daily papers detailing the dreadful situation that fateful morning carried a shipment of $\$ 3,500.00$ gold coin to the Iowa National Bank, our Des Moines correspondent. About 1:00 p.m. the cashier, Harry' T. Blackburn, called me on the phone, and in a tone of voice suggestive of a man about to announce the sudden death of his wife, said he assumed I knew of "the awful situation facing the banks." He felt he should warn me that if the gold shipment was placed to our credit he would not obligate his bank to supply us with currency should we later need it, and if with this understanding I wished he would return the shipment unopened. I replied that if we had needed it I would not have sent it to them, but if unwilling to later supply us if needed, he need not either credit nor return, but hold in their burglar-proof vaults, subject to our order.

After reading the sensational news broadcast via the public press many of our customers called to ascertain what it was all about, and particularly as to our policy in limiting legitimate withdrawals. I had to tell them we knew nothing other than what we and they had read in the papers, that for the present at least we proposed to do business as usual, and that as long as they continued to deposit their cash that long we would continue to pay in full all legitimate demands.

We were not long in learning that a few frightened bankers were scaring a lot of people. The two railroads passing through our town had long followed the custom of exchanging their cash and local check collections for Chicago drafts instead of sending cash to headquarters. This custom was discontinued and agents instructed to 
remit cash only. Wholesalers and jobbers instructed their salesmen to take no checks in payment on accounts, but to collect cash only and remit by registered mail or retain and carry until their weekend return.

\section{Country Banks More SANE}

At a midweek assemblage of Marion county bankers at Knoxville, after careful consideration and discussion, it was decided to make no change so far as their own customers were concerned, but to cash no checks other than their own, and each to make daily reports to an appointed committee as conditions developed. Our bank carried a lot of coal miners' savings accounts and well did I know what would happen if any of them should ask for his money and it was not immediately forthcoming in full. One or two did come in, asked for and was paid as usual. He reported to his co-workers and friends that we were with-holding no part of their money and no trouble was experienced.

Lawrence was negotiating the purchase of the Dick Sullivan farm. Price and terms had been agreed upon, providing for a down payment of $\$ 1,000.00$ cash, no checks, drafts nor cashier checks acceptable. Shaw called to ascertain if he could get his money in cash. Thus assured, a few hours later purchaser and seller returned together. Shaw presented his CD and I placed in front of Sullivan fifty twenty dollar gold coins. Steadily eyeing them for a moment he pushed them back with a remark, "I don't want to carry that d-n stuff," and asked for a time $\mathrm{CD}$, which he received, and he too went away happy.

Our cash continued to increase until I was afraid to carry so much in our safes without additional insurance and so complained to J. B. Elliott, president of the Knoxville National Bank, another of our local correspondents. He then told me I might send it to them and he would provide all the currency we might require in the future. During the approximately sixty days the fiasco contin- 
ued we shipped some forty or fifty thousand dollars, taken in over the counter in excess of what we were called to pay out. The Iowa National advised it was ready to credit our account with the $\$ 3,500.00$, that so far as being of benefit to any one had just as well have been in the bottom of the sea. My experience confirmed my oft expressed belief that to be perfectly frank and honest, to hide nothing from our depositors is the best policy, though I admit I lost some much needed sleep and was relieved when normal conditions again prevailed.

The debacle of 1921 was far the worst this country had ever experienced. When I left for Council Bluffs in 1918 James T. Doughman was assistant cashier. Two years later he became executive cashier. To his good judgment and careful management is largely due the safe piloting of the bank through the long perilous years, though ably assisted by his son, Edward G. Doughman, who entered the bank as assistant cashier and is now the capable and popular president of the State Bank of Bussey, the incorporated old Bank of Bussey.

Our competitor and rival, the Bussey Savings Bank, organized in 1907 for the declared purpose of putting us out of business, in 1931 was taken over by our old bank to prevent its involuntary closing and consequent heavy loss to depositors in event of receivership. Except for the stigma of a closed bank in town, and consequent uneasiness of the banking public, we might have been better off had we let matters take the usual and natural course.

When we opened in 1892 we were the seventh bank in the county. The maximum in 1919 was about thirty, now reduced by closings and reorganizations to twelve. Excepting one we are the oldest bank in the county, and one of three that did not go through the process of reorganization, for which result I am only too glad to credit James T. and Edward G. Doughman. They did a good job. 
Copyright of Annals of Iowa is the property of State of Iowa, by \& through the State Historical Society of Iowa and its content may not be copied or emailed to multiple sites or posted to a listserv without the copyright holder's express written permission. However, users may print, download, or email articles for individual use. 